\title{
Carlos Thiebaut y Antonio Gómez Ramos, Las razones de la amargura: variaciones y tientos sobre el resentimiento, el perdón y la justicia, Barcelona, Herder, 2018, 312 pp.
}

$\square_{y}^{1}$ libro que Carlos Thiebaut nos ofrecen en esta oportunidad gira en torno al resentimiento; y utilizo la palabra "gira" porque las reflexiones que allí se desarrollan no se enfocan tanto en la naturaleza de la "cosa misma", sino en las dimensiones que el resentimiento comunica y/o obstruye, y que en su conjunto hacen a muchos de los tópicos que la ética y filosofía política exploran. De esta forma, y movidos por dispares inquietudes, ambos autores concuerdan en que el resentimiento abriga un valioso componente normativo que merece ser tematizado y problematizado a contrapelo de la dominante postura que cree ver en aquel una perversión, o incluso enfermedad anímica y moral. Por ello el libro se titula Razones de la amargura y no El resentimiento y sus implicaciones: el desafio sería recoger la racionalidad que se resiste a ser olvidada en el daño,y en aquella demanda suya que muchas veces (sino las más) ni siquiera llega a ser articulada comunicativa o recognoscitivamente, y que por ello no puede sino crecer deformada dentro de la memoria, obligando a su agente a desarrollar complejos aprendizajes para no quedar varado en el dolor.

La vía que escogen para tratar este asunto es el de la conversación: un diálogo dentro del cual la segunda persona del singular logra establecer algo de la intimidad y visceralidad de las aflicciones que mueven a los autores a explorar los componentes normativos del resentimiento. En virtud de ello, el libro no puede sino asumir un estilo ensayístico que, entre otras cosas, le permite al lector un acercamiento bastante llano a los argumentos expuestos. Esto se debe al hecho de que la conversación pone de relieve un mutuo esfuerzo por lograr el entendimiento, el intercambio eficiente, en pos de alcanzar algo razonable de forma solidaria, lo cual se agradece en una era en la que los intercambios y las compilaciones suelen ser más una colección de argumentos que una búsqueda cooperativa de la mejor comprensión de un problema.

Pero la conversación no carece de la pretensión de universalidad que suele distinguir a toda discusión filosófica. En particular, porque ambos autores se posicionan como "espectadores" (blancos y europeos) del resentimiento ajeno. De ahí que la conversación comience discutiendo y finalmente justificando esta posición de espectador a partir de los casos paradigmáticos de Max Horkheimer (en tanto burgués que empatiza con el sufrimiento proletario) y Jaime Gil de Biedma (en tanto consciente de que su consciencia no le exoneraba de sus complicidades), al punto de elaborar la noción de "co-resentimiento" (cap. 1 y 2): una especie de sensibilidad moral 
que le permitiría al espectador aprender a escuchar el sufrimiento ajeno y separar la paja del trigo al atender las razones de sus amarguras.

El co-resentimiento excluiría la necesidad de recurrir a las no poco importantes investigaciones que desarrolla la psicología moral, puesto que aquello que estaría en juego sería la reconstrucción de la racionalidad que se esconde en todo resentimiento ajeno. Ningún autor niega las vertientes pesimistas (aquellas que, a partir de Nietzsche, Dostoievsky y Scheller, ven una depravación subjetiva en el Ressentiment) ni optimistas (las que desde el mundo anglosajón perciben algo moral en el resentment) del resentimiento, lo cual les permite navegar dentro de los matices que revela esta emoción al poner de relieve sus orígenes, transfiguraciones creativas y persistencias temporales dentro de la memoria personal. De esta forma, los casos de Jean Améry y Antjie Krog (caps. 7 y 8) cobran una relevancia sin igual dentro de la conversación: ambos creen que Améry y Krog son capaces de "poner" (Setzen) las dos caras del resentimiento, aunque expiándolo de formas diferentes, dentro de contextos también diferentes. Uno, en tanto resentido que se esfuerza por autoarticularse y autoexpresarse comunicativamente como testimonio vivo y autorreflexivo del Holocausto, y la otra, en tanto testigo del resentimiento ajeno que se asume cómplice del apartheid, son capaces de mostrar lo insorteablemente individualizador y desolador que es el proceso de subjetivación que tiene la posibilidad de recorrer el resentido. Por este motivo es que la escucha, y no la psicología moral, gozaría de cierta prioridad dentro de los procesos de comprensión y evaluación pública de las razones que pudie- ran atrincherarse tras aquella emoción.

A diferencia del odio, el resentimiento aísla, y por ello constituye una fuerza netamente individualizadora. Solo puede accederse a él desde la primera y segunda personas, siendo la mutua y personal opacidad algo a asumir en el encuentro y no a negar o intentar eliminar. Dificilmente pueda hablarse de una sociedad resentida, puesto que el resentimiento solo es vivido desde la primera persona y empatizado desde la segunda. De hecho, una de las coordenadas que hacen a la intensa fuerza individualizadora del resentimiento guarda relación con la "mutante persistencia" del daño, y concomitante amargura, que se habría vivido en el pasado: esta persistencia, que no deja de tener sus opacidades, se imprime sobre (o produce) un yo sufriente pretérito que dificulta de sobremanera el libre habitar temporal del presente y del futuro. Sin embargo, esta obstaculización individual que Nietzsche entendía enfermiza, también supone una resistencia al olvido del daño, de la amargura que este ocasiona desde entonces, y de las razones que justifican el actual "estar" o "ser" resentido: resentirse es, entre otras cosas, re-sentir-se dañado en un presente que se ata al pasado (caps. 3 y 4 ).

Como se ha dicho, la individualización que promueve el resentimiento no puede sino descansar en una amargura que abriga razones; y estas razones no pueden dejar de ser atendibles para un otro que escucha con el tacto adecuado. De ahí que los autores exploren tres figuras que podrían colaborar con la "clausura del daño" que origina el resentimiento: el perdón, la justicia y la reconciliación. Las tres figuras responden al tipo de razones que fundan las demandas de la amargura, las cuales bien 
pueden estar dirigidas hacia un individuo en concreto, hacia una institución, o hacia una comunidad. Para el primer caso, las demandas se articulan de tú-atú, y por ello es que pueden aspirar a conseguir el arrepentimiento y el perdón; para el segundo, las demandas que guardan relación con las dignidades personales, y por ello, con las autocomprensiones jurídicas que se rigen por el respeto, caben ser resueltas retributivamente en términos de "justicia restaurativa"; para el último caso la comunidad tendría la oportunidad de asumir y apropiar errores que pudieron ocasionar daños en el pasado, y lograr con ello una suerte de autorreconciliación en términos hegelianos.

Claro está que esas figuras suponen elementos nada fáciles de sostener (como lo es el asunto de qué es lo que se debe reconciliar cuando nada en común tienen la víctima y el victimario -caps. 9 y 10-). Pero a pesar de que aquellas no llegan a ser conceptualizadas completamente, los autores las utilizan para avanzar notas acerca de la naturaleza de la actitud que les subyace, a saber, las de la escucha, atención, y paciencia (cap. 11).Y esto lo hacen a través de una delgada vía negativa que se trabaja a uno y otro lado, una que a veces es anecdótica (como el caso del paseo por el Canal de Berlín a Spandau, que se relata y analiza urbana y arquitectónicamente con un estilo narrativo exquisito), otras vivenciales (como sucede cuando comentan el caso de los atentados etarras en España), y otras comentadas desde la postura de espectadores bien informados y autoconscientes de sus limitaciones (lo que ocurre a lo largo de los extensos comentarios que le dedican al Truth and Reconciliation Commission de Sudáfrica). Esta delgada vía negativa les permite visibilizar cómo el resentimiento puede formar parte de una sociedad libre que aspire a la justicia, cuando en ella habitan individuos que son capaces de autoarticularse y comunicar a los demás las razones de sus amarguras, y/o escuchar y atender esas expresiones en los demás.

La conversación parece estar bastante lejos de concluir. No solo por lo que aún tengan para agregar sus autores, sino porque el acercamiento y las preguntas que proponen suscitan la prolongación de esta conversación en otros lugares. Sobre todo porque las generalizaciones que caracterizan al pensamiento filosófico nos seducen a preguntarnos si, por ejemplo, las democracias advenidas luego de los gobiernos militares del Cono Sur han sabido escuchar $\mathrm{y}$ atender aquellos resentimientos que se generan desde la década del 70 a la fecha. Uno de los méritos más destacables de Razones de la amargura estriba en que alienta el diálogo que se compromete a alcanzar una comprensión adecuada de todo lo que "gira" en torno al resentimiento. Un libro "anómalo e infrecuente", confiesan y advierten sus autores, que aporta mucho a la comprensión de las razones que abrigan algunas amarguras: aporta estilo, ideas, y una camaradería que se propicia por ciertas formas de escuchar y de ser paciente.

MARTÍN FLEITAS GONZÁLEZ UdelaR 